\begin{tabular}{|c|c|}
\hline 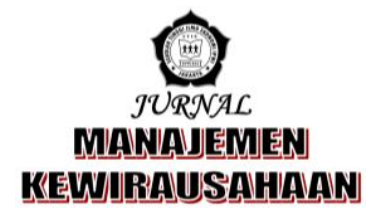 & $\begin{array}{r}\text { p-ISSN 1858-1048 } \\
\text { e-ISSN 2654-9247 } \\
\text { http://ejurnal.stieipwija.ac.id/index.php/jmk } \\
\text { DOI: http://dx.doi.org/10.33370/imk.v16i1.307 } \\
\text { Jurnal Manajemen Kewirausahaan Vol. 16 No. 01 - Juni } 2019 \\
\text { Submit: 10 Mei 2019; Review: 17 Jun 2019; Publish: 30 Jun } 2019\end{array}$ \\
\hline
\end{tabular}

\title{
PENGARUH KEPUASAN KERJA, STRES KERJA, DAN BUDAYA PERUSAHAAN TERHADAP TURNOVER INTENTION
}

\author{
Oleh: \\ Joni Heruwanto'), Heri Haripriana'), Rasipan ${ }^{3)}$ \\ joniheruwanto@yahoo.com ${ }^{1)}$, heripriyana@yahoo.com ${ }^{2}$, ipan081267@yahoo.com ${ }^{3)}$ \\ Sekolah Tinggi Ilmu Ekonomi IPWI Jakarta1,2,3)
}

\begin{abstract}
ABSTRAK
Penelitian ini dilakukan untuk mengetahui pengaruh kepuasan kerja, stress kerja, dan budaya perusahaan terhadap turnover intention pada PT. Lion Mentari Airlines di Bandara Soekarno - Hatta.

Penelitian dilakukan pada PT. Lion Mentari Airlines di Bandara Soekarno - Hatta. Dengan mengambil 100 responden sebagai sampel penelitian. Pengambilan data dilakukan dengan menggunakan teknik unprobability sampling dengan pendekatan purposive sampling.

Penelitian menghasilkan tiga temuan utama sesuai dengan hipotesis yang diajukan, yaitu: 1) Hasil penelitian ini membuktikan bahwa kepuasan kerja berpengaruh signifikan terhadap turnover intention; 2) Hasil penelitian ini membuktikan bahwa stress kerja tidak berpengaruh signifikan terhadap turnover intention; 3) Hasil penelitian ini membuktikan bahwa budaya perusahaan berpengaruh signifikan terhadap turnover intention.
\end{abstract}

Kata Kunci: kepuasan kerja, stres kerja, budaya perusahaan, turnover intention

\section{PENDAHULUAN}

Suatu perusahaan dikatakan berhasil atau sukses ketika indikator turnover karyawannya rendah dengan kata lain karyawan sudah di-manage dengan baik dan benar oleh perusahaan. Turnover memang bukan satu-satunya indikator kesuksesan perusahaan namun beberapa pengelola SDM menilai bahwa indikator ini sangat dipengaruhi banyak faktor sehingga akan sulit mencapai angka turnover yang rendah.

Sumber Daya Manusia merupakan asset paling penting dalam sebuah perusahaan, tanpa ada manusia maka sumber daya perusahaan tidak akan dapat menghasilkan laba atau menambah nilainya sendiri. Terlebih lagi bagi sebuah perusahaan yang menawarkan jasa, dimana sumber daya manusia memegang peran penting sebagai ujung tombak perusahaan.

Salah satu upaya untuk mencapai tujuan yang diinginkan perusahaan dengan meminimalisasi tingkat perputaran karyawan (employee's turnover) dengan menperhatikan segala faktor yang menyebabkan keinginan karyawan untuk berpindah (turnover intention). Intensi turnover diartikan sebagai keinginan atau niat tenaga kerja untuk keluar dari perusahaan.

Dalam mengelola sumber daya manusia yang paling utama adalah bagaimana meningkatkan kinerja perusahaan atau mempertahankan kinerja perusahaan agar tetap tinggi walaupun dengan kondisi adanya 
frekuensi keluar masuk karyawan yang tinggi. Oleh sebab itu para pengelola sumber daya manusia perlu bekerja keras dalam mempertahankan karyawan yang ada dengan segala kemampuannya.

\section{TUJUAN PENELITIAN}

1. Untuk mengetahui pengaruh kepuasan kerja terhadap turnover intention pada PT. Lion Mentari Airlines.

2. Untuk mengetahui pengaruh stres kerja terhadap turnover intention pada PT. Lion Mentari Airlines.

3. Untuk mengetahui pengaruh budaya perusahaan terhadap turnover intention pada PT. Lion Mentari Airlines.

\section{TELAAH LITERATUR DAN PENGEMBANGAN PROPOSISI/HIPOTESIS Kepuasan Kerja}

Menurut Ghozali (2006:159), kepuasan kerja adalah kondisi menyenangkan atau secara emosional positif yang berasal dari penilaian seseorang atas pekerjaannya atau pengalaman kerjanya. Ada beberapa teori kepuasan kerja yang dijelaskan di bawah ini:

1. Two Factor Theory

Two factor theory adalah teori yang mengemukakan bahwa kepuasan dan ketidakpuasan meruapakan bagian dari kelompok variabel yang tidak sama yaitu motivators dah hygiene factors. Ketidakpuasan berkaitan dengan kondisi disekitaran pekerjaan contohnya kondisi kerja, gaji, safety, kualitas pengawasan dan hubungan dengan orang lain dan bukan dengan pekerjaan itu sendiri.

2. Value Theory

Berdasarkan teori ini, kepuasan kerja terjadi di tingkatan dimana hasil pekerjaan diterima oleh individu seperti yang diharapkan. Jika hasil yang diterima semakin banyak, maka semakin puas dan sebaliknya. Kunci dalam menuju kepuasan dengan teori ini adalah perbedaan antara aspek pekerjaan yang dimiliki dengan yang diinginkan seseorang. Jika semakini besar perbedaan, maka semakin rendah kepuasan seseorang.

3. Teori Ketidaksesuaian

Teori ini menyarankan bahwa setiap orang menginginkan supaya sejumlah pekerjaan yang telah disumbangkan kepada pemberi karyawan akan dihargai sebesar yang diterima secara kenyataan.

4. Teori Keadilan

Dalam teori ini menunjukkan kepada seseorang merasa puas atau tidak puas tergantung kepada perasaan adil (equity) atau tidak adil (inequity). Perasaan adil dan tidak adil terhadap suatu situasi diperoleh setiap orang dengan cara membandingkan dirinya dengan orang lain di tingkat dan jenis pekerjaan yang sama, di tempat yang sama ataupun berbeda.

\section{Stres Kerja}

Menurut Handoko (2001:200), stres kerja adalah suatu kondisi ketegangan yang mempengaruhi proses berpikir, emosi, dan kondisi seseorang, hasilnya stres yang terlalu berlebihan dapat mengancam kemampuan seseorang untuk menghadapi lingkungan dan pada akhirnya akan mengganggu pelaksanaan tugas-tugasnya. Penyebab stres kerja menurut Robbins (2008:370), terdapat 3 kategori potensi pemicustres kerja, hal tersebut antara lain:

a. Faktor Lingkungan

Faktor lingkungan dapat dikelompokkan menjadi 3 bagian, diantaranya:

1) Selain mempengaruhi desain struktur perusahaan, ketidakpastian lingkungan juga mempengaruhi tingkat stres karyawan dalam perusahaan. Perubahan dalam siklus bisnis menciptakan ketidakpastian ekonomi.

2) Ketidakpastian politik juga dapat menjadi pemicu stres diantara karyawan.

3) Perubahan teknologi juga dapat menyebabkan stres, karena inovasi baru yang bisa membuat bentuk inovasi teknologi lain yang serupa 
merupakan ancaman bagi banyak orang dan membuat mereka stres.

b. Faktor Perusahaan

Faktor perusahaan dikelompokkan menjadi 3 bagian, diantaranya:

1) Tuntutan tugas adalah faktor yang terkait dengan pekerjaan seseorang, mencakup desain pekerjaan individual, kondisi kerja dan tata letak fisik pekerjaan.

2) Tuntutan peran merupakan beban berlebihan yang dialami saat karyawan diharapkan menjalankan lebih banyak peran daripada waktu yang ada.

3) Tuntutan antarpribadi merupakan tekanan yang diciptakan oleh karyawan lain, tidak adanya dukungan dari teman dan hubungan antarpribadi yang buruk bisa menyebabkan stres.

c. Faktor Pribadi

Faktor pribadi ini menyangkut masalah keluarga, masalah ekonomi pribadi serta kepribadian dan karakter yang melekat pada diri seseorang. Berbagai kesulitan dalam perkawinan, retaknya hubungan dan kesulitan masalah disiplin dengan anak merupakan masalah hubungan yang memicu stres bagi karyawan yang kemudian terbawa hingga ke tempat kerja. Masalah ekonomi yang dialami akan menciptakan stres bagi karyawan dan mengganggu konsentrasi kerja.

\section{Budaya Organisasi}

Menurut Robbins (2008) budaya organisasi adalah sebagai sebuah sistem makna bersama yang dianut oleh para anggota organisasi yang membedakan organisasi tersebut dengan organisasi yang lain. Sistem makna bersama ini merupakan sekumpulan karakteristik kunci yang dijunjung tinggi oleh organisasi.

Dalam budaya organisasi ada teori yang membahas simbol komunikasi seperti kebiasaan, perilaku dan perkataan dan makna yang ada pada simbol tersebut. Konteksnya seperti pada perusahaan, budaya organisasi dipercaya sebagai salah satu cara organisasi untuk dapat mencapai tujuan dan keberhasilan. Teori budaya organisasi memiliki asumsi dasar yang dijelasksan di bawah ini:

1. Para anggota organisasi membuat dan mempertahankan perasaan yang dimiliki secara bersama pada kenyataan yang ada di organisasi tersebut, yang menjadi pemahaman yang lebih baik atas nilai suatu organisasi. Inti dari hal ini adalah apa yang ada pada organisasi tersebut. Nilai adalah standar dan prinsip yang ada di dalam budaya organisasi.

2. Penggunaan dan interpreatasi dari simbol yang penting di dalam budaya organisasi. Ketika ada orang yang memahami ini maka orang ini akan dapat melaksanakan hal-hal yang ada pada budaya organisasi tersebut.

3. Budaya yang bervariasi di dalam organisasi yang berbeda, dan interpretasi tindakan di dalam budaya juga sangat bervariasi. Dalam hal ini setiap organisasi memiliki budaya yang tidak sama dan setiap individu dalam organisasi tersebut memiliki tafsiran budaya yang tidak sama. Seperti pada umumnya, perbedaan dalam berorganisasi akan menjadi sebuah kekuatan dari organisasi sejenis lain.

\section{Turn Over Intention}

Menurut Supriyanto (2003), yang dimaksud turnover yaitu proporsi jumlah anggota organisasi yang secara sukarela (voluntary) dan tidak (non voluntary) meninggalkan organisasi dalam kurun waktu tertentu. Umumnya dinyatakan dalam satu tahun, turnover tidak boleh $10 \%$ per tahun. Hal yang perlu dipahami untuk menemukan definisi umum turnover, antara lain:

1. Turnover berfokus pada karyawan, dalam arti mereka yang menerima upah dari organisasi suatu kondisi yang menunjukan keanggotaan dari organisasi sebagai suatu kondisi yang menunjukan keanggotaan karyawan dalam organisasi.

2. Turnover berfokus pada penghentian atau pemisahan diri karyawan dari organisasi.

3. Definisi umum turnover dapat dipakai untuk berbagai tipe 
organisasi dan pada berbagai macam tipe hubungan karyawan organisasi.

Turnover intention diindikasikan sebagai sikap individu yang mengacu pada hasil evaluasi mengenai kelangsungan hubungannya dengan organisasi dimana dirinya bekerja dan belum terwujud dalam bentuk tindakan pasti

\section{Hipotesis}

Menurut Sugiyono (2013:93), hipotesis merupakan jawaban sementara terhadap rumusan masalah penelitian, oleh karena itu rumusan masalah penelitian dikatakan sementara, karena jawaban yang diberikan baru didasarkan pada fakta-fakta empiris yang diperoleh melalui pengumpulan data. Jadi hipotesis juga dapat dinyatakan sebagai jawaban teoritis terhadap rumusan masalah penelitian, bukan jawaban yang empiris.

Berdasarkan rumusan masalah dan hasil penelitian-penelitian sebelumnya maka dapat ditarik hipotesis sebagai sebagai berikut:

H1: Adanya pengaruh kepuasan kerja terhadap turnover intention

H2: Adanya pengaruh stres kerja terhadap turnover intention

H3: Adanya pengaruh budaya perusahaan terhadap turnover

\section{METODE PENELITIAN \\ Sampel Penelitian}

Sampel menurut Sugiyono (2013:81) adalah bagian dari jumlah dan karakteristik yang dimiliki oleh populasi tersebut. Teknik pengambilan sample pada penelitian ini menggunakan unpobability sampling. Teknik untuk menentukan sample dari populasi yang mempunyai ciri-ciri tertentu. Peneliti mengambil sampel sebanyak 100 karyawan di PT. Lion Mentari Airlines unit kerja back office Bandara SoekarnoHatta.

\section{Desain Penelitian}

Variabel penelitian menurut Sugiyono (2013:38) pada dasarnya adalah segala sesuatu yang berbentuk apa saja yang ditetapkan oleh peneliti untuk dipelajari sehingga diperoleh informasi tentang hal tersebut, kemudian ditarik kesimpulannya.

a. Variabel Bebas (Independence

Variabel)

Variabel independen ini sering disebut variabel stimulus, predictor, antecedent. Dalam Bahasa Indonesia sering disebut sebagai variabel bebas. Menurut Sugiyono (2013:39) variabel bebas adalah merupakan variabel yang mempengaruhi atau yang menjadi sebab perubahannya atau timbulnya variabel dependen (terikat).

Dalam penelitian ini yang menjadi variabel bebas adalah sebagai berikut:

$\mathrm{X} 1$ = Kepuasan Kerja

$\mathrm{X} 2$ = Stres Kerja

X3 = Budaya Perusahaan

b. Variabel Terikat (Dependence Variabel)

Variabel dependen sering disebut sebagai variabel output, kriteria, dan konsekuen. Dalam Bahasa Indonesia sering disebut variabel terikat. Menurut Sugiyono (2013:39) variabel terikat merupakan variabel yang dipengaruhi atau menjadi akibat, karena adanya variabel bebas atau disebut variabel independen. Dalam penelitian ini yang menjadi variabel terikat adalah sebagai berikut: $\mathrm{Y}=$ Turnover Intention

\section{Operasionalisasi Variabel}

Definisi variabel merupakan petunjuk bagaimana suatu variabel diukur dalam sebuah penelitian. Variabel dalam penelitian ini ditentukan berdasarkan landasan teori yaitu kepuasan kerja, stres kerja, budaya perusahaan, dan turnover intention. Secara operasional variabel tersebut didefinisikan sebagai berikut:

1. Kepuasan Kerja (X1)

Luthans (2006) menyebutkan bahwa kepuasan kerja merupakan keadaan emosi yang senang atau emosi yang positif yang berasal dari penilaian kerja atau pengalaman kerja seseorang. Terdapat lima faktor yang 
mempengaruhi kepuasan kerja, yaitu (Luthans, 2006):

- Pekerjaan itu sendiri, dalam hal dimana pekerjaan memberikan tugas yang menarik, kesempatan untuk belajar, dan kesempatan untuk menerima tanggung jawab.

- Gaji, sejumlah upah yang diterima dan tingkat dimana hal ini bisa dipandang sebagai hal yang dianggap pantas dibandingkan dengan orang lain dalam organisasi.

- Supervisi, kemampuan untuk memberikan bantuan teknis dan dukungan perilaku.

- Rekan kerja tingkat dimana rekan kerja pandai secara teknis dan mendukung secara sosial.

- Kesempatan promosi, kesempatan untuk maju dalam organisasi.

2. Stres Kerja (X2)

Mangkunegara (2005) menyatakan bahwa stres kerja adalah perasaan yang menekan atau merasa tertekan yang dialami karyawan dalam menghadapi pekerjaan. Stres kerja diukur melalui empat indikator yakni:

- Beban kerja, yaitu sekumpulan tugas dan pekerjaan yang berkaitan dengan organisasi dan harus diselesaikan dalam waktu tertentu.

- Waktu kerja, yaitu suatu periode waktu yang mengikat karyawan dalam melaksanakan pekerjaan berkaitan dengan organisasi.

- Umpan balik yang didapatkan, yaitu suatu respon tindakan yang diberikan atasan, bawahan dan rekan kerja terhadap tindakan yang dilakukan.

- Tanggung jawab, yaitu keadaan wajib memikul dan menanggung semua konsekuensinya yang berkaitan dengan pekerjaan dan jabatan yang diemban.

3. Budaya Perusahaan (X3)

Menurut Robbins (2008) mendefinisikan bahwa budaya organisasi adalah sistem makna bersama yang dianut oleh anggota- anggota yang membedakan organisasi itu dari organisasiorganisasi lain. Ada tujuh karakteristik utama secara keseluruhan merupakan hakikat budaya organisasi, diantaranya:

- Inovasi dan pengambilan resiko, dilihat dari sejauh mana para karyawan didorong untuk bersikap inovatif dan kreatif dan berani mengambil resiko.

- Perhatian ke hal yang rinci. Sejauh mana para karyawan mau memperlihatkan kecermatan, analisis perhatian kepala rincian.

- Orientasi hasil. Sejauh mana manajemen fokus pada hasil, bukan pada teknik dan proses yang digunakan untuk mendapatkan hasil itu.

- Orientasi orang. Sejauh mana keputusan manajemen memperhitungkan efek hasil pada orang-orang di dalam organisasi itu.

- Orientasi tim. Sejauh mana kegiatan kerja diorganisasikan dalam tim-tim kerja, bukannya individu-individu.

- Keagresifan. Sejauh mana orang-orang itu agresif dan kompetitif, bukan bersantai.

- Kemantapan. Sejauh mana kegiatan organisasi menekankan dipertahankannya status quo sebagai lawan dari pertumbuhan atau inovasi.

4. Turnover Intention (Y)

Turnover intention diartikan sebagai kecenderungan atau niat karyawan untuk berhenti bekerja dari pekerjaannya secara sukarela atau pindah dari satu tempat ke tempat kerja yang lain menurut pilihannya sendiri (Mobley, 1986). Turnover yang dibahas dalam penelitian ini adalah dalam konteks model sukarela (voluntary turnover). Variabel turnover intention diukur dengan tiga item yang menggali informasi mengenai keinginan responden untuk mencari pekerjaan lain. Item pengukuran tersebut terdiri atas: 
- Kecenderungan individu berpikir untuk meninggalkan organisasi tempat ia bekerja sekarang.

- Kemungkinan individu akan mencari pekerjaan pada organisasi lain.

- Kemungkinan meninggalkan organisasi.

\section{Metode Analisis}

\section{Analisis Statistik Deskriptif}

Menurut Sugiyono (2013:147) statistik deskriptif adalah statistik yang digunakan untuk menganalisis data dengan cara mengdeskripsikan atau menggambarkan data yang lebih terkumpul sebagaimana adanya tanpa bermaksud membuat kesimpulan yang berlaku untuk umum atau generalisasi.

a. Uji Validitas

Menurut Imam Ghozali (2013:52), uji validitas untuk mengukur sah atau valid tidaknya suatu kuesioner. Suatu kuesioner dikatakan valid jika pertanyaan pada kuesioner mampu untuk mengungkapkan sesuatu yang akan diukur oleh kuesioner valid.

Pada penelitian ini, uji validitas akan dilakukan dengan bantuan program SPSS (Stastistical Package for Social Sciences). Untuk menentukan nomor-nomor item yang valid dan yang gugur, perlu dikonsultasikan dengan Table $r$ Products Moment. Menurut Sugiyono (2014:128) Kriteria penilaian uji validitas adalah sebagai berikut:

- Apabila $r$ hitung > $r$ Tabel, maka item kuesioner tersebut valid.

- Apabila $r$ hitung < $r$ Tabel, maka item kuesioner tersebut tidak valid.

- Adapun teknik korelasi yang biasa dipakai adalah teknik korelasi product moment, untuk mengetahui perhitungan valid atau tidaknya dengan menggunakan rumus sebagai berikut:

$$
n=\frac{N}{1+(N \times e)^{2}}
$$

Sumber: Juliansyah Noor $(2015: 157)$

Dimana:

$\mathrm{X}=$ skor yang diperoleh subjek dari seluruh item

$\mathrm{Y}=$ skor total yang diperoleh dari seluruh item

$\Sigma \mathrm{X}=$ jumlah skor dalam $\mathrm{x}$

$\Sigma Y=$ jumlah skor dalam y

$\Sigma \mathrm{X}^{2}=$ jumlah kuadrat dalam skor $\mathrm{x}$

$\Sigma Y^{2}=$ jumlah kuadrat dalam skor $y$

$\mathrm{N}=$ banyaknya responden

b. Uji Reliabilitas

Menurut Imam Ghozali (2016:47) reliabilitas yaitu alat untuk mengukur suatu kuesioner yang merupakan alat pengukuran konstruk atau variabel. Suatu kuesioner dikatakan reliabel atau handal jika jawaban seseorang terhadap pertanyaan adalah konsisten atau stabil dari waktu ke waktu.

Pengujian reliabilitas dengan internal consistency dengan teknik belah dua (split half) yang dianalisis dengan rumus Spearman Brown, sebagai berikut:

$$
r_{i}=\frac{2 . r_{b}}{1+r_{b}}
$$

Sumber: Sugiyono 2013:131

Dimana:

$$
\begin{aligned}
\mathrm{ri}= & \text { reliabilitas internal seluruh } \\
& \text { instrumen } \\
\mathrm{rb}= & \text { korelasi prodouct moment } \\
& \text { antara belahan pertama dan } \\
& \text { kedua }
\end{aligned}
$$

\section{Pengujian Hipotesis}

Uji yang digunakan untuk menyatakan signifikan pengaruh variabel bebas secara parsial terhadap variabel terikat, langkah-langkah:

a. Uji Parsial (Uji t)

Untuk menguji signifikan koefisien korelasi products moment menggunakan uji t, yang dihitung dengan rumus: 


$$
t=\frac{R \sqrt{n-2}}{\sqrt{1-R^{2}}}
$$

Sumber : Sugiyono (2013:257)

Keterangan:

$\mathrm{t}=$ nilai $\mathrm{t}$ hitung

$\mathrm{R}=$ koefisien korelasi

$\mathrm{n}=$ jumlah sampel

$\mathrm{R} 2=$ koefisien determinasi

Uji t digunakan untuk mengetahui apakah masing-masing variabel bebas secara sendiri-sendiri berpengaruh signifikan terhadap variabel terikatnya. Kriteria pengujian, jika:

- $\mathrm{t}$ hitung > $\mathrm{t}$ tabel, maka Ho ditolak atau Ha diterima. Artinya terdapat pengaruh yang signifikan antara kepuasan kerja, stres kerja dan budaya perusahaan terhadap turnover intention.

- $\quad \mathrm{t}$ hitung < $\mathrm{t}$ tabel, maka Ho diterima atau Ha ditolak. Artinya tidak terdapat pengaruh yang signifikan antara kepuasan kerja, stres kerja dan budaya perusahaan terhadap turnover intention.

b. Uji Simultan (Uji F)

Uji $F$ adalah pengujian signifikan persamaan yang digunakan untuk mengetahui seberapa berpengaruhnya antara tiga variabel bebas, kepuasan kerja X1, stres kerja X2, dan budaya perusahaan X3 terhadap variabel terikat yaitu turnover intention $\mathrm{Y}$ secara bersamaan, sehingga dapat diketahui dengan yang sudah ada apakah dapat diterima atau ditolak. Adapun rumus yang dipakai oleh penulis adalah sebagai berikut:

$$
F=\frac{R^{2} / k}{\left(1-R^{2}\right)(n-k-1)}
$$

Sumber: Sugiyono (2013:266)

Keterangan:

$\mathrm{F}=$ nilai $\mathrm{t}$ simultan

$\mathrm{R}=$ koefisien korelasi ganda

$\mathrm{k}=$ jumlah variabel independen

$\mathrm{n}=$ jumlah sampel
Uji $\mathrm{F}$ digunakan untuk mengetahui pengaruh variabel secara bersamasama antara dua variabel bebas. Kriteria pengujian, jika:

- $\mathrm{F}$ hitung > $\mathrm{F}$ tabel, maka Ho ditolak atau Ha diterima. Artinya terdapat pengaruh yang signifikan antara kepuasan kerja, stres kerja dan budaya perusahaan terhadap turnover intention.

- $\mathrm{F}$ hitung < $\mathrm{F}$ tabel, maka Ho diterima atau Ha ditolak. Artinya tidak terdapat pengaruh yang signifikan antara kepuasan kerja, stres kerja dan budaya perusahaan terhadap turnover intention.

\section{HASIL DAN PEMBAHASAN \\ Hasil Penelitian \\ Gambaran Objek Penelitian}

Objek penelitian dalam penelitian ini adalah para karyawan back office di PT. Lion Mentari Airlines. Kuisioner disebar secara langsung kepada para karyawan back office di PT. Lion Mentari Airlines. Total kuisioner yang disebar sebanyak 100 lembar.

\section{Deskripsi Responden}

1. Jenis Kelamin

Berdasarkan jenis kelamin responden terdiri dari 2 kategori, yaitu pria dan wanita. Dari hasil data yang diperoleh dan yang digunakan peneliti sebanyak (78) responden adalah pria dan (22) responden adalah wanita.

2. Usia

Mengenai umur responden juga bervariasi. Responden yang berumur 18-20 tahun sebanyak (7) orang (7\%), untuk umur 21-23 tahun sebanyak (16) orang (16\%), dan umur 24-26 tahun sebanyak (12) orang $(12 \%)$, serta umur lebih dari 26 tahun sebanyak (65) orang atau sekitar (65\%).

\section{Uji Validitas dan Reliabilitas Variabel Kepuasan Kerja (X1)}

Berdasarkan hasil analisis yang telah dilakukan, dalam pengujian 
validitas data dilakukan dengan menggunakan pendekatan korelasi bivariate dapat diketahui bahwa nilai dari masing-masing pertanyaan yang digunakan dalam variabel penelitian mempunyai nilai corrected item-total corelation yang lebih besar dari $r$ tabel dimana $\mathrm{N}=100$ dengan probabilitas 0,10 $(10 \%)$. Uji validitas variabel kepuasan kerja dilakukan terhadap 10 item pertanyaan, maka 10 item pertanyaan pengukur variabel kepuasan kerja seluruhnya valid.

Pada penelitian ini dalam menghitung reliabilitas data dilakukan dengan alat uji cronbch alpha. Hasil pengolahan data variabel kepuasan kerja mengenai koefisien reliabilitas (cronbach's alpha) berdasarkan hasil SPSS adalah 0,874. Nilai koefisien ini jika dibandingkan dengan nilai perbandingan $(0,60)$ ternyata masih lebih besar $(0,874$ $>0,60$ ), sehingga instrumen ini dapat dikatakan reliabel.

\section{Uji Validitas dan Uji Reliabilitas Variabel Stres Kerja (X2)}

Berdasarkan hasil analisis yang telah dilakukan dalam pengujian validitas data, dilakukan dengan menggunakan pendekatan korelasi bivariate dapat diketahui bahwa nilai dari masing-masing pernyataan yang digunakan dalam variabel penelitian memiliki nilai corrected item-total correlation yang lebih besar dari $r$ tabel dimana $\mathrm{N}=100$ dengan probabilitas sebesar $0,10(10 \%)$. Uji validitas variabel stres kerja dilakukan terhadap 10 item pertanyaan, maka 10 item pertanyaan pengukur variabel stres kerja seluruhnya valid.

Pada penelitian ini dalam menghitung reliabilitas data dilakukan dengan alat uji cronbach alpha. Hasil pengolahan data variabel kepuasan kerja mengenai koefisien reliabilitas (cronbach's alpha) berdasarkan hasil SPSS adalah 0,820. Nilai koefisien ini jika dibandingkan dengan nilai perbandingan $(0,60)$ ternyata masih lebih besar $(0,820$ $>0,60$ ), sehingga instrumen ini dapat dikatakan reliabel.

\section{Uji Validitas dan Uji Reliabilitas Variabel Budaya Perusahaan (X3)}

Berdasarkan hasil analisis yang telah dilakukan dalam pengujian validitas data, dilakukan dengan menggunakan pendekatan korelasi bivariate dapat diketahui bahwa nilai dari masing-masing pernyataan yang digunakan dalam variabel penelitian memiliki nilai corrected item-total correlation yang lebih besar dari $r$ tabel dimana $\mathrm{N}=100$ dengan probabilitas sebesar $0,10(10 \%)$. Uji validitas variabel budaya perusahaan dilakukan terhadap 10 item pertanyaan, dari 10 butir pertanyaan pada variabel yang diuji terdapat satu butir pertanyaan yang tidak valid karena memiliki nilai corrected item-total correlation $>0,3$ yaitu butir nomor X304 $(0,238)$. Satu butir pertanyaan yang tidak valid tersebut dikeluarkan dan diuji kembali sehingga hanya 9 item pertanyaan pengukur variabel budaya perusahaan yang dinyatakan valid.

Pada penelitian ini dalam menghitung reliabilitas data dilakukan dengan alat uji cronbach alpha. Hasil pengolahan data variabel kepuasan kerja mengenai koefisien reliabilitas (cronbach's alpha) berdasarkan hasil SPSS adalah 0,830. Nilai koefisien ini jika dibandingkan dengan nilai perbandingan $(0,60)$ ternyata masih lebih besar $(0,830$ $>0,60)$, sehingga instrumen ini dapat dikatakan reliabel.

\section{Uji Validitas dan Uji Reliabilitas Variabel Turnover Intention (Y)}

Berdasarkan hasil analisis yang telah dilakukan dalam pengujian validitas data, dilakukan dengan menggunakan pendekatan korelasi bivariate dapat diketahui bahwa nilai dari masing-masing pernyataan yang digunakan dalam variabel penelitian memiliki nilai corrected item-total correlation yang lebih besar dari $r$ tabel dimana $\mathrm{N}=100$ dengan probabilitas sebesar $0,10(10 \%)$. Uji validitas variabel budaya perusahaan dilakukan terhadap 10 item pertanyaan, dari 10 butir pertanyaan pada variabel yang diuji terdapat satu butir pertanyaan yang tidak valid karena memiliki nilai 
corrected item-total correlation $>0,3$ yaitu butir nomor Y10 $(0,244)$. Satu butir pertanyaan yang tidak valid tersebut dikeluarkan dan diuji kembali sehingga hanya 9 item pertanyaan pengukur variabel budaya perusahaan yang dinyatakan valid.

Pada penelitian ini dalam menghitung reliabilitas data dilakukan dengan alat uji cronbach alpha. Hasil pengolahan data variabel kepuasan kerja mengenai koefisien reliabilitas (cronbach's alpha) berdasarkan hasil SPSS adalah 0,874. Nilai koefisien ini jika dibandingkan dengan nilai perbandingan $(0,60)$ ternyata masih lebih besar $(0,874$ $>0,60$ ), sehingga instrumen ini dapat dikatakan reliabel.

\section{Analisis Regresi Linier Berganda}

Dari output pengujian regresi linier berganda dengan tingkat signifikansi sebesar 0,011<0,10 (X1), 0,652 >0,10 (X2), dan 0,000 < 0,10 (X3) maka Ho ditolak dan Ha diterima untuk variabel kepuasan kerja (X1), Ho diterima dan $\mathrm{Ha}$ ditolah (X2), dan Ho ditolak dan $\mathrm{Ha}$ diterima (X3). Dengan kata lain ada pengaruh variabel kepuasan kerja (X1), variabel stres kerja (X2), dan variabel budaya perusahaan (X3) terhadap variabel turnover intention $(\mathrm{Y})$.

\section{Koefisien Korelasi $R$ dan Determinan $\boldsymbol{R}$ Square (R2)}

Berdasarkan pengujian diperoleh nilai koefisien korelasi $\mathrm{R}=0,661$. Koefisien korelasi ini menujukan bahwa hubungan simultan antara variabel independen (X1, X2, dan X3) dengan variabel dependen $(\mathrm{Y})$. Koefisien determinan ganda ganda atau $\mathrm{R}$ Square = 0,437, angka ini menunjukan bahwa secara simultan variabel independen (X1, $\mathrm{X} 2$, dan $\mathrm{X} 3$ ) mempunyai variabel dependen (Y) sebesar 43,7\% sedangkan sisanya $(100 \%-43,7 \%=56,3 \%)$ dipengaruhi oleh variabel lain atau variabel $Y$ secara simultan oleh variabel $\mathrm{X} 1, \mathrm{X} 2$, dan X3 sebesar 43,7\%.

\section{Uji Signifikansi Pengaruh Parsial (Uji} t)

Tabel 1

Coefficients $^{\mathrm{a}}$

\begin{tabular}{|l|c|c|c|c|c|}
\hline \multirow{2}{*}{\multicolumn{1}{|c|}{ Model }} & \multicolumn{2}{|c|}{$\begin{array}{c}\text { Unstandardized } \\
\text { Coefficients }\end{array}$} & $\begin{array}{c}\text { Standardized } \\
\text { Coefficients }\end{array}$ & & \\
\cline { 2 - 5 } & $\mathrm{B}$ & Std. Error & Beta & $\mathrm{t}$ & Sig. \\
\hline 1 (Constant) & -.094 & .446 & & -.210 & .834 \\
Kepuasan Kerja & .303 & .117 & .273 & 2.594 & .011 \\
Stres Kerja & .069 & .154 & .055 & .452 & .652 \\
Budava Perusahan & .575 & .131 & .440 & 4.376 & .000 \\
\hline
\end{tabular}

a. Dependent Variable: Turnover Intention

Sumber: Data diolah SPSS 21

1. Pengaruh parsial $\mathrm{X} 1$, terhadap $\mathrm{Y}$ ditunjukan oleh koefisien regresi X1 sebesar b1 0,303. Berdasarkan output SPSS pada tabel coefficients dapat diketahui nilai $\mathrm{t}$ terhitung $=$ 2,594 dan nilai $\mathrm{t}$ tabel $=1,66055$ dengan probabilitas sig $=0.011$. Karena $\mathrm{t}$ terhitung 2,594 $>\mathrm{t}$ tabel 1,66055 atau nilai sig $(0.011)<0,10$, maka Ho ditolak dan Ha diterima. Jadi kesimpulan secara parsial variabel $\mathrm{X} 1$ berpengaruh terhadap variabel $\mathrm{Y}$.

2. Pengaruh parsial $\mathrm{X} 2$ terhadap $\mathrm{Y}$ ditunjukan oleh koefisien regresi X2 sebesar b2 =0,069. Berdasarkan output SPSS pada tabel coefficients dapat diketahui nilai t hitung $=0,452$ dan $\mathrm{t}$ tabel $=1,66055$ dengan probilitas sig. $=0,652$. Karena $t$ hitung $0,452<\mathrm{t}$ tabel 1,66055 atau nilai sig. (0.652) > 0,10; maka Ho ditolak dan $\mathrm{Ha}$ diterima. Jadi kesimpulan secara parsial variabel $\mathrm{X} 2$ tidak berpengaruh terhadap variabel Y.

3. Pengaruh parsial X3 terhadap $\mathrm{Y}$ ditunjukan oleh koefesien X3 sebesar b3 $=0,575$. Berdasarkan output SPSS pada tabel coefficients dapat diketahui nilai t hitung $=4,376$ dan $\mathrm{t}$ tabel $=1,66055$ dengan probilitas sig. $=0,000$. Karena $\mathrm{t}$ hitung 4,376 $>\mathrm{t}$ tabel 1,66055 atau nilai sig. $(0,000)<$ 0,10 ; maka Ho ditolak dan $\mathrm{Ha}$ diterima. Jadi kesimpulan secara parsial variabel $\mathrm{X} 3$ berpengaruh terhadap variabel $\mathrm{Y}$. 
Uji Signifikansi Pengaruh Simultan (Uji F)

Tabel 2

ANOVA $^{\mathrm{a}}$

\begin{tabular}{|l|c|c|c|c|c|}
\hline \multicolumn{1}{|c|}{ Model } & $\begin{array}{c}\text { Sum of } \\
\text { Squares }\end{array}$ & df & $\begin{array}{c}\text { Mean } \\
\text { Square }\end{array}$ & F & Sig. \\
\hline 1 Regression & 17.307 & 3 & 5.769 & 24.849 & $.000^{\circ}$ \\
Residual & 22.287 & 96 & .232 & & \\
Total & 39.594 & 99 & & & \\
\hline
\end{tabular}

a. Dependent Variable: Turnover Intention

b. Predictors: (Constant), Budaya Perusahan, Kepuasan Kerja, Stres Kerja

Sumber: Data diolah SPSS 21

Berdasarkan tabel Anova nilai $F$ hitung $=24,849$ dan $\mathrm{F}$ tabel $=2.36$ dengan nilai sig. $=0.000$. Ternyata nilai $\mathrm{F}$ hitung $=24,849>\mathrm{F}$ tabel $=2.36$ atau nilai sig. $(0,000)<0,10$, dengan demikian Ho ditolak dan $\mathrm{Ha}$ diterima. Jadi kesimpulannya adalah secara simultan variabel $\mathrm{X} 1, \mathrm{X} 2$, dan $\mathrm{X} 3$ memberikan pengaruh yang signifikan terhadap variabel Y.

\section{KESIMPULAN}

\section{Simpulan}

1. Kepuasan kerja berpengaruh signifikan terhadap tingkat turnover intention di PT. Lion Mentari Airlines Bandara Soekarno-Hatta.

2. Stres kerja tidak berpengaruh signifikan terhadap tingkat turnover intention di PT. Lion Mentari Airlines Bandara Soekarno-Hatta.
3. Budaya perusahaan berpengaruh signifikan terhadap tingkat turnover intention di PT. Lion Mentari Airlines Bandara Soekarno-Hatta.

\section{DAFTAR PUSTAKA}

Ghozali, Imam. (2009). Aplikasi Analisis Multivariate dengan Program SPSS (4 ed). Semarang: Badan Penerbit Universitas Diponegoro.

Handoko, T. Hani. (2001). Manajemen Personalia dan Sumber Daya Manusia (14 ed). Yogyakarta: BPFE.

Luthans, Fred. (2006). Perilaku Organisasi (V. Yuwono, dkk, Alih Bahasa. Bahasa Indonesia ed). Yogyakarta: ANDI.

Mangkunegara. (2005). Manajemen Sumber Daya Perusahaan. Bandung: PT. Remaja Rosda Karya.

Mobley, W. H. (1986). Pergantian Karyawan: Sebab-Akibat dan Pengendaliannya. Jakarta: PT. Pustaka Binaman Pressindo.

Noor, Juliansyah. (2015). Metodologi Penelitian. Jakarta: Kencana.

Robbins. (2008). Perilaku Organisasi. Jakarta: PT. Indesk Kelompok Gramedia.

Sugiyono. 2013. Metode Penelitian Pendidikan Pendekatan Kuantitatif, Kualitatif dan $R \& D$. Bandung: Alfabeta. 